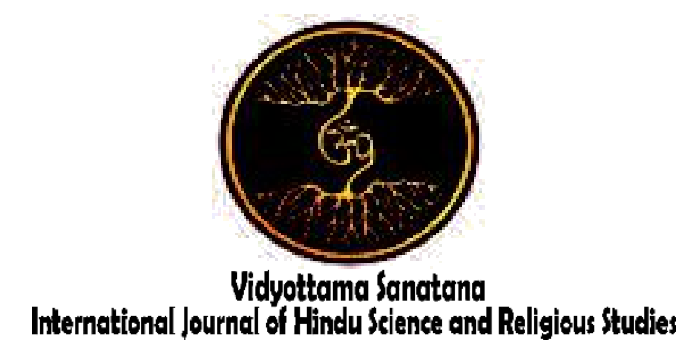

Vol. 2 No. 2 October 2018

\title{
Ethic Educations Of Leadership In Tenganan Pegringsingan Traditional Village
}

\author{
By: \\ Putu Ersa Rahayu Dewi ${ }^{1}$, I Gede Suwindia ${ }^{2}$, I Ketut Sudarsana ${ }^{3}$ \\ ${ }^{123}$ Institut Hindu Dharma Negeri Denpasar \\ E-mail: ${ }^{1}$ Ersarahayu14@gmail.com, ${ }^{2}$ windia_gede@yahoo.com, ${ }^{3}$ iketutsudarsana@ihdn.ac.id \\ Received: August 21, 2018 \\ Accepted: September 20, 2018 \\ Published: October 31, 2018
}

\begin{abstract}
Every village has a leader. The uniqueness of the leadership of Tenganan Pegringsingan village is interesting to be observed. Therefore, the researcher is interested to observe it with three main problems as follows: 1.How is the leadership system in Tenganan Pegringsingan traditional village? 2. How is the job and leadership function in Tenganan Pegringsingan traditional village? 3 . How is the ethics education in leadership system in Tenganan Pegringsingan? with the general objects and specific objects and also the benefits of theoretical and practical. Furthermore, theoretical mapping in this study uses as follows: 1 . system theory to distinguish the problem of leader system; 2. structural functional theory to distinguish the problem about the leadership's job and the function; 3 . the value theory to distinguish the problem of leadership ethics education. Whereas, the method used is the method of collecting data as the beginning for accuracy and foresight in preparing the thesis. The method of collecting the data as follows: observation method, interview method, library method, and method of documentation study. After the data collected and processed by using descriptive analysis method is how data processing is done by the way of arranging systematically to get the general conclusion. Based on the research methods, the result of the study can be describe as follows: 1. leadership system of Tenganan Pegringsingan traditional village such as: a. general leadership; b. the role of traditional village; c. devotion of leadership rules; $d$. the level of krama desa's structure; e. the relationship between traditional village and the government; f. routine krama desa activities. 2. Tenganan Pegringsingan's duties and functions of village leadership such as: a. tradition and religion functions; $b$. political and the law function; c. social and civic security function. 3. Leadership ethics education such as: a. ehical education in taking decision; b. ethical education in rituals and religions; c. ethical education in environmental management; d. ethical education in maintaining tradition and culture.
\end{abstract}

Keywords: Ethical education, Leadership system. 


\section{Introduction}

Bali is one of the regions that still maintain the procedures for leadership processes that is appropriate with the inherited culture to make each village safer and and the community has ethical behavior. As a village leader is not easy because before nominates as a leader, they have fulfilled the specifications of being a leader. When the candidate of leader is ready to nominate himself, then the village community carries out the election of a leader, however, in the election of a leader there will be a difference between one village and another, even though it has the same purpose. In Bali Aga village whose people still maintain the traditions, customs and culture in the process of forming a leader. Before becoming a main leader or called "Luanan", they have to face several stages. The formation of a leader in the traditional village is not based on voting but through a natural process that the community itself does not know when they will be a new leader.

The structure of "krama desa" consists of the main part which is called "luanan" who is often called penglingsir (which is elder) in Bali in general, the luanan has the duties and functions as advisors in structural organizations in the Tenganan Pegringsingan Traditional Village. Luanan is a retiree from Keliang Adat (Kelihan), who has gone through all stages of the "krama desa" organization, from the smallest to the Keliang Adat. Furthermore, under Luanan, there is a "klian adat" who has a function as a leader of krama desa, and is responsible for all forms of activities in the village, both in the form of religious activities and social activities. Under Keliang Adat, there are "bahan roras", which have duties and functions as "pentarikan desa" (Secretary). Further, "Juru arah" that is under from the "bahan roras". Generally in Bali "juru arah" is often called as "Kesinoman", which has the function of the task of providing direction or information to the village officials related to all forms of activities in the Traditional Village in the form of religious activities and social activities. The lowest part of the village structural organization is the "krama desa" (villagers), who have the task function of supporting and assisting all forms of activities in the Desa Adat Tenganan Pegringsingan, religious activities and social activities in the village.

\section{Method}

Method is a procedure or method to find out something that has systematic steps. The method as a tool used in data collection in research. In carrying out research using a variety of methods to achieve research objectives through the research process (Arikunto, 2006: 160). Data obtained in the study of Ethics Education in the Leadership System in the Traditional Village of Tenganan Pegringsingan, Manggis distruct, Karangasem regency. In obtaining complete data is intended to obtain field data as the constituent material of the research in order to reveal the focus of the research under observation.The interview method is a data collection technique that is carried out by holding a question and answer session, either directly or indirectly to the informant to obtain information about the issues being discussed. While literature studies, carried out to collect data through sources of literature, documentation, photographs and books that have been studied by previous researchers, necessarily, the book has relevance to the problems in this study, namely about Ethics Education in Leadership Systems to support and strengthen results research.

\section{Results and Discussion}

Tenganan Pegringsingan traditional village community is one of the people who still have good ethics and morals. Obedience to the rules of adat village is an obligation that should be carried out by all of "krama desa". Before becoming a member of the leadership system, the village man followed the first "Pati Panten" and brought the name of the house which was not the same as the general name used on the birth certificate. 
According to the traditional village of Tenganan Pegringsingan there is no specific purpose in changing the name at Bale Agung, only this has been done since long time ago. This name is only used specifically in Bale Agung, which is when the ceremony or outing is the name that will be used when attending the counting of the number of village attendees present and those not present. Candidates for "krama desa" who do not carry names, members of the "krama desa" who will make a name at Bale Agung. Then the "pati panten" begins and is finished, the candidate of "krama desa" officially becomes a new member of the Tenganan Pegringsingan village. The names used in Bale Agung according to the chart above. This name will be celebrated as the beginning of being a "krama desa". The name can be chosen is freely according to the wishes of the candidate of "krama desa". When it is legitimate to become a member of the "krama desa", they occupy the lowest position as a new man who adapts himself and learns to carry out village activities according to duties and functions that have been traditionally determined.

The current village structure only reaches "Tambalapu" because there are no additional members of the "krama desa". Luanan is the highest position in the "krama desa" structure. Luanan is a person who is elder, leader or who has the most experience in "krama desa". Luanan is the one who is the elder and leader who is highly respected by the "krama desa" because he has extensive experience of ceremonies, traditions, customs in the traditional village of Tenganan Pegringsingan which has been carried out so far. The existence of "luanan" is certainly because it has been through a long process in "krama desa" that being a "luanan" is a very lucky thing for the perpetrators of "krama desa" because not all "krama desa" in the "krama desa" structure can reach the process up to "luanan". No one can oppose the luanan or even fight, because the big sanctions when there are "krama desa" who are without considering with luanan. The education process takes place in every activity carried out because luanan as leaders who when attending village activities must be picked up, are not allowed to walk alone without invitation from subordinate of "krama desa". Luanan is divided into 5 sections according to the chart above. Beside the "luanan satu" no one occupies because there is a luanan or something where the luanan is "niskala" which is believed by the "krama desa" to be present when there is a meeting or ceremony at Bale Agung, it's just not mentioned in the "krama desa", only 5 of "luanans" are mentioned. The five luanans are the elders or people who are elder by the traditional village of Tenganan Pegringsingan.

Luanan became a more special person because he did not take part in routine activities at Bale Agung every day which was held every evening at around 8 o'clock. The assignment is just little bit, only if there was a big problem that occurred in the village then, "Luanan" who was responsible because "Luanan" was the council advisor in the traditional village of Tenganan Pegringsingan. To achieve the luanan process, all of "krama desa" cannot predict when the position of the "luanan" is still in him because only life will answer it and like humans who do not know when we will die. Luanan position is the highest position but previously passed the lowest position. Luanan also passed the position of being a "tambalapu" to the "bahan". Thus the "luanan" will know how the tasks contained in the Tenganan Pegringsingan traditional village. Then under the luanan there is a position called "bahan". "Bahan" is divided into two parts, namely "Bahan duluan" and "Bahan tebenan". "Bahan duluan" consists of 6 people and the "bahan tebenan" also consists of 6 people. "Bahan" and "Bahan duluan" is the "klian desa" who controls every activity in the Tenganan Pegringsingan traditional village there are 2 people who become "tamping takon" which is taken from the "Bahan duluan satu" and "Bahan duluan dua" are called "tamping takon 
duluan" and "tamping takon tebenan". "Bahan roras" has direct duties and responsibilities in traditional activities and the implementation of traditional ceremonies. "Bahan" was born from "tambalapu" who then rises into a "bahan" position. Technical and implementation of ceremonies or traditions that will be conducted every month or "sasih" according to the traditional village calendar of Tenganan Pegringsingan is fully delegated to "roras material", and if there is a problem or proposal then "tamping takon duluan" has the right to make the right decision every problem that exists but has previously been coordinated with "bahan satu" to "bahan enam duluan". "Bahan roras" also has the task as "penyarikan" in turn from "bahan tebenan enam" then upwards which will be replaced every month, that is each "pati panten" activity, activities carried out by "penyarikan" in addition to recording every activity that will be carried out of "pati panten" and also when "sangkep" has a task of playing kulkul 21 times every morning precisely at 6:00 a.m. If "Bahan" has a job as a "Penyarikan" but gets an assignment from the village to follow the activities out of the village that cannot be left, then it can be replaced by "penyarikan perempuan". furthermore, the same "tambalapu" which consisted of six people of "tambalapu duluan" and six "tambalapu tabenan". "Tambalapu" is the beginning of the "krama desa" which has just entered the "krama desa" precisely will occupy the bottom position of "tambalapu". There is no word that "Tambalapu" is a person who does not have power or anything else however "krama desa" are need of "tambalapu" because they are the ones who will prepare the facilities and infrastructure that will be needed when there will be different ceremonies and traditions every time in accordance with the traditional village calendar of Tenganan Pegringsingan. Tambalapu where the beginning of the learning process became "krama desa" which later could make traditional villages become more preserving their culture. "Tambalapu" has a very hard task in every process of ritual activities that will be held. "Saye" is found in the village which will inform each activity in the "krama desa" as well as the task section of the "tambalapu". Saye is replaced every month at the time of the "pati panten" activity, saye every month there are 4 people and start from the bottom of "tambalapu" to the top. When one of the "saye" is unable to attend with a reason that can be accepted by the "luanan" or the "bahan", the other "saye" who carries out the task. "Saye" will "ngatag" every day, if "ngatag" in 2 times it means there are no activities to be held tomorrow but if "ngatag" in 3 times it means there will be activities tomorrow. Although it can only be delivered during the morning or afternoon, the function of "ngatag" is reminder of the "krama desa" that there will be activities tomorrow or not. Then the position under "tambalapu" is a "pengeluduan" which later if there is a new "krama desa" then the position of "tambalapu is full, hence, the "krama desa" will enter in the "pengeluduan". "pengeluduan" is not limited in number but still in structure of "krama desa". The activities that will be carried out by "pengeluduan" is same as "tambalapu". Furthermore, there are "nandes" or "malang" leaders or "patih desa". These "Nandes" are not chosen or according to "karma desa" structure but the "nandes" are chosen according to their descent. "Nandes" has subordinates called "malang" who will assist every village activity or the process of carrying out ceremonies or activities of the traditional village of Tenganan Pegringsingan. For example, in the village activities, materials are needed that have to look out of the village, so these "malangs" people will help it. Thus the activities that are routinely carried out at each time will be known by each "krama desa". then if the general "pemangku" will lead the traditional village ceremonial activities but in the Tenganan Pegringsingan traditional village, beside as a leader when the ceremony will be 
held but also "pemangku" must carry out traditional village activities according to their duties and functions in the " krama desa" structure. "Krama desa" is the hope of the village as the successor of the ceremony of the Tenganan Pegringsingan traditional village ceremony, thus, each "krama desa" receives compensation from the traditional village in the form of staple and materials in accordance with their duties and functions in the traditional village. In this case the "tambalapu" group receives more compensation from the village each month than "bahan" and "luanan" because as "tambalapu" is the most difficult in carrying out the ceremonies of each month and the tasks that the "tambalapu" must be done. According to Sudiastika (interview, 17 April 2018), it was stated that every people who had entered the "krama desa" must follow the rules that had been enacted. There is no error term that is solely made to seek sensation or something else. Adherence to the rules makes "krama desa" increasingly have characteristically behavior in order to advance the traditional village of Tenganan Pegringsingan by maintaining the customs, culture, traditions and ceremonies that have been handed down from generation to generation.

However, as a human being it is not perfect, sometimes, people made mistakes whether intentionally or not. In the Tenganan Pegringsingan traditional village taught the "krama desa" to remain a discipline because if "krama desa" makes a mistake, they will get customary sanctions without exception. This avoids human behavior every time changes occur, thus "krama desa" will become more disciplined, careful or introspective and pay more attention to the surrounding environment. "Krama desa" have to obedient to the existing rules, something that is not intentional will cause new problems which will later impact the village activities that will be held. Some of the violations is founded by "krama desa" in Tenganan Pegringsingan traditional village such as "keris" is used when wearing traditional clothing fell accidentally, there is "tedunan desa" but is absent for no apparent reason, arguing when the "petedunan", did not complete the ceremonial facilities assigned to search and not join in "megebegan". The examples that have been mentioned are those which are categorized as mild because if "keris" that is used when you are dressed in custom, it happens of course because of accident, even though it has been placed correctly but at times it will fall. Then arguing when the "petedunan", it is carried out when there would be activities carried out by the traditional village however, in the middle of the of "petedunan", there are new ideas that cause a gap between "krama desa". then when the ceremony will be held in the Tenganan Pegringsingan traditional village, the "krama desa" gets the parts of the ceremony which must be prepared for the ceremony to be held, but one of the "krama desa" who does not follow and meets all the infrastructure that must be sought, the "krama desa" will be sanctioned agreed upon according to what has been applied. While the other examples of severe customary sanctions are the first to remarry, in Hinduism it is permissible to remarry when the mate dies or is legitimate in the State administration apart from the previous mate, however, if this happens in the Tenganan Pegringsingan traditional village then the "krama desa" is right to be issued from "krama desa", its not only this mistake, if there is one "krana desa" having a position as a "tambalapu" then cutting down a lot of trees, the "tambalapu" has the right to get sanctions because it is assumed that the position has is still lower than "bahan", but if the position of "bahan" reaches cutting down trees carelessly, "tamping takon" has the task of removing the "krama desa" in "krama desa" members and not getting compensation from the village every month, not only that the "krama desa" are never present every time there is a "tedunan" for a long time then the "krama desa" can be removed from Tenganan Pegringsingan traditional village, and if one of the "krama 
desa" stole a crime at Bale Agung, the "krama desa" had to leave the "makrama desa".

The relationship of the leadership system with ethics education is in the leadership system in the Tenganan Pegringsingan traditional village there are some activities that include the ethics of the community in carrying out these activities. Ethics education plays an important role because in the leadership system, members of "krama desa" are not permitted to step past the field and "bahan" as the person in the leadership system. Krama desa realizes that whatever is done either intentionally or not will get the results that have been done. Mutual respect is an important way in the leadership system in the Tenganan Pegringsingan traditional village.

By implementing ethics education in a steady, creative and dynamic to "krama desa" and community, a harmonious life is realized which includes the development of a whole human being devoted to Sang Hyang Widhi Wasa / Tuhan Yang Maha Esa (parahyangan), peace with others (pawongan) and love environmental sustainability (palemahan) which will ultimately create harmony in the overall relationship, especially in Tenganan Pegringsingan traditional village, Manggis District, Karangasem Regency.

\section{Conclusion}

Based on the results of the research analysis above, the researcher can be concluded from the study entitled "Ethics Education in the Leadership System in the Tenganan Pegringsingan of traditional village, Manggis District, Karangasem Regency as follows; The leadership system in the Tenganan Pegringsingan traditional village is divided into the top one, namely "luanan" consisting of 5 people, then there are 12 people divided into two parts, namely 6 parts of the "bahan duluan" which is often called "klian desa", "klian desa" number one and two called "tamping takon duluan" and "tamping takon tebenan" the other 6 "bahan" is then called "bahan tebenan", under the "bahan" , the members of the "krama desa" namely "tambalapu" and are divided into two parts, and "tambalapu duluan" and "tambalapu tebenan" that totaling 12 people. If the members of the "krama desa" more than the "tambalapu" limit, then the new village will enter to "pengeluduan" and the number is unlimited, the last is "nandes". The leadership system is based on the "awigawig" Tenganan Pegringsingan traditional village in the implementation of traditional village activities, there are rules that are adhered and prohibitions are avoided customary sanctions.

The task and function of the leadership system in the Tenganan Pegringsingan traditional village, Manggis district, Karangasem regency in terms of three aspects. The first is customary and religious functions, namely "keama desa" carry out traditional and religious activities such as rituals and traditions in accordance with the tasks that have been known to each other when entering into "krama desa", the second is political and legal functions, namely "krama desa" who have authority in the political function of responsibility fully held by "klian desa", then for the legal function "tamping takon" has a function to issue decisions when there are members or "krama desa" who make big mistakes that can harm "krama desa" even to the detriment traditional villages, luanan as advisors when "tamping takon" involved in the deliberations but still cannot give a decision and when they cannot provide input or advice, they are invited "klian gumi" as the former of "krama desa" who come out of the village on the grounds of marriage to provide input and advice which is appropriate and can provide the right decision without any element of injustice, the third is social and social security functions, namely "krama desa" except the "luanan" has the duty to protect the security of the village and the environment around the Tenganan traditional village with "tambalapu" and "bahan" who take turns on duty of "magebagan" in Bale 
Agung to plan development, mutual cooperation, etc. so that the Tenganan Pegringsingan traditional village community is not easily affected in the current era, thus, the waning of customs and culture of ancestral heritage is thus expected to preserve the traditional culture and traditions inherited by ancestors.

Ethics education in the leadership system in the traditional village of Tenganan Pegringsingan, Manggis Subdistrict, Karangasem Regency, as follows; firstly, ethical values in decision-making, namely "krama desa" who make decisions must be in accordance with the rules that apply not based on their own desires, secondly, ethical values in rituals and religions, namely "krama desa" following religious activities accordingly and carrying out religious activities sincerely and respecting the "krama desa luanan" and "bahan" as leaders in religious activities, thirdly, Ethical values in environmental management are that "krama desa" are not permitted to cut trees or damage village-owned land, sanctions that given in accordance with violations to double the price of things then exit from "krama desa", therefore, the rules can make Tenganan Pegringsingan of traditional village still continues to preserve the environment until now there has been no shift in land area, fourthly, ethical values in the defense of adat and culture, namely "krama desa" while maintaining "samodana" language as a special language in Tenganan Pegringsingan when going to carry out religious offerings or activities and carry out their duties and functions then follow the rules that have been applied so that the ceremony can proceed properly without any lack of facilities used.

\section{References}

Arikunto, Suharsimi. 2013. Proses Penelitian suatu Pendekatan Praktik. Yogyakarta. Rineka Cipta

Gulo, W. 2004. Metodologi Penelitian. Jakarta: Pt. Gramedia

Kusumawardhani, Sri.2006.Panduan Praktis Penulisan Karya Ilmiah dan Proposal. Diktat Kuliah penulisan Karya Ilmiah Institut Hindu Dharma Negeri Denpasar

Riduwan. 2004. Metode dan Teknik Penyusunan Tesis. Bandung: Alfabeta

Suci, I. G. S., Sonhadji, A., Imron, A., \& Arifin, I. (2018). Organizational Harmony in Hindu Higher Educatiob Institution based on Tri Hita Karana Culture. Vidyottama Sanatana: International Journal of Hindu Science and Religious Studies, 2(1), 49-59.

Sugiyono.2006. Metode Penelitian Kualitatif, Kuantitatif dan $R \& D$. Bandung: Alfabeta

Sugiyono. 2007. Metode Penelitian Kualitatif. Bandung: Alfabeta

Sugiyono. 2009. Penelitian Pendidikan. Bandung: Alfabeta

Warsana, I. N. (2017). Pattern Of Adolescent Learning Hindu Scholarship Recruits Through Pasraman Widya Dharma Saraswati. Vidyottama Sanatana: International Journal of Hindu Science and Religious Studies, 1(2), 168-178. 